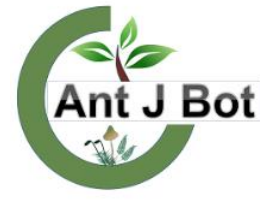

Received : 05.03.2021 Accepted : 16.05.2021 Online : 04.06 .1021

\section{Phenolic screening and biological activities of Chenopodium botrys $\mathbf{L}$. extracts}

\author{
Ela Nur ŞiMŞEK SEZER ${ }^{1} \odot^{*}$, Tuna UYSAL ${ }^{2} \odot$ \\ ${ }^{1,2}$ Selçuk University, Science Faculty, Dept. of Biology, Konya, Turkey \\ *elasimsek@selcuk.edu.tr, ${ }^{2}$ tuysal@selcuk.edu.tr
}

\section{Chenopodium botrys L. ekstraktlarının fenolik taraması ve biyolojik aktiviteleri}

\begin{abstract}
The genus Chenopodium is a genus that includes over 200 species and contains annual or perennial herbaceous flowering plant species scattered almost worldwide. While species belonging to the Chenopodium genus are used to treat various diseases, modern pharmaceutical research has revealed their strong anticancer, antifungal and antibacterial potential. In this study, some biological effects of Chenopodium botrys (methanol and ethanol) extracts were evaluated by helping some analytical approaches. The antioxidant and cytotoxic potentials of the extracts were revealed. In this study, 4 phenolic components in the extracts were determined with the HPLC technique and to determine the antioxidant activity of the plant extracts TPC (total phenolic content), RPA (reducing power activity), and DPPH (2,2'-diphenyl-1-picrylhydrazyl) methods were used. MTT (3(4,5-dimethylthiazol-2-yl)-2,5-diphenyltetrazolium bromide) assay was used to determine the cytotoxic effect of the extracts on the HL60 cell line. The results showed that both extracts have important properties that should be evaluated, and especially the ethanolic extract is more effective than the methanolic extract in all aspects (TPC, antioxidant capacity, and cytotoxicity). As a conclusion, it is clear that this plant needs to be investigated further for the isolation and characterization of new and effective phytochemicals. We hope that this study could be a precursor for future studies.
\end{abstract}

Key words: Antioxidant, HPLC, HL60, MTT, phenolic

Özet: Chenopodium cinsi, 200'den fazla türe sahip ve hemen hemen tüm Dünya'da yayılış gösteren tek yıllık veya çok yillık otsu çiçekli bitki türlerini içeren bir cinstir. Chenopodium cinsine ait türler çeșitli hastalıkların tedavisinde kullanılırken, modern farmasötik araştırmalar güçlü antikanser, antifungal ve antibakteriyel potansiyellerini ortaya çıkarmıştır. Bu çalışmada, Chenopodium botrys (metanol ve etanol) ekstraktlarının bazı biyolojik etkileri (antioksidan ve sitotoksik potansiyelleri), çeșitli analitik yaklaşımlar yardımıyla değerlendirilmiştir. Çalışmada ekstraktlarda bulunan 4 fenolik bileşenin tespiti HPLC tekniği ile yapılmış, bitkinin antioksidan aktivitesini belirlemek için TPC, RPA ve DPPH yöntemleri kullanılmıştır. Ekstraktların HL60 hücre hattı üzerindeki sitotoksik etkisini belirlemek için ise MTT testi kullanılmıştır. Sonuçlar, her iki ekstraktın da değerlendirilmesi gereken önemli özelliklere sahip olduğunu ve özellikle etanolik ekstraktın her yönden (TPC, antioksidan kapasite ve sitotoksisite) metanolik ekstrakttan daha etkili olduğunu göstermiştir. Sonuç olarak, yeni ve etkili fitokimyasalların izolasyonu ve karakterizasyonu için bu bitkinin daha fazla araştırılması gerektiği açıktır. Bu çalışmanın gelecekteki çalışmalar için bir öncü olabileceğini umuyoruz.

Anahtar Kelimeler: Antioksidan, fenolik, HPLC, HL60, MTT

Citation: Şimșek Sezer EN, Uysal T (2021). Phenolic screening and biological activities of Chenopodium botrys L. extracts. Anatolian Journal of Botany 5(2): 78-83.

\section{Introduction}

Medicinal and aromatic plants are so productive that they have had many uses such as food, medicine, cosmetics, and spices for years, and they are known to have been used for similar purposes since the beginning of human history. Herbal therapy is preferred in many countries globally, especially in undeveloped countries, under different names such as traditional therapy, complementary therapy, natural treatment, and information and inferences are made every day (Acrbuca and Budak, 2018). According to the World Health Organization (WHO), three-quarters of the world's population resort to solutions (herbs) for public health. It is estimated that up to four billion people living in the world rely on herbal medicinal products as the primary source of health care, and traditional medical practice, which includes the use of herbs, is seen as an integral part (Bodeker et al., 2005; Bandaranayake, 2006; Ekor, 2014). In addition to herbal treatments' widespread and economic nature, many people turn to phytotherapy as it is regarded as an alternative to modern medicine. In Turkey, extracts obtained from various parts of plants (leaves, flowers, bark, or other parts) by different methods are widely used in the treatment and/or preventing many diseases, from cancer to diabetes (Bozyel et al., 2019).

Chenopodium L. is a genus that includes single or perennial herbaceous flowering plant species that spread almost anywhere in the world and has more than 200 species. There are 15 species belonging to the genus Chenopodium in Turkey (Güner et al., 2012). Chenopodium botrys L. species, known by the public, is widely distributed in Turkey and grows naturally in the West and Central Black Sea, Inner West Anatolia, Upper Sakarya, and Middle Kizılırmak and Adana sections (Güner et al., 2012). The herb has various uses in traditional medicine; there are studies on the use of the plant in the treatment of cold and asthma and the analgesic, anthelmintic, and headacherelieving effects of the leaves. Many Chenopodium species have been reported to be used in traditional therapy and have numerous medicinal properties. The species included in the genus are used in the treatment of various diseases, especially chest complaints, cough, abdominal pain, lung obstruction, and nervous disorders (Yadav et al., 2007). Chenopodium botrys L., which are spread in various regions of the world, have different usage areas for each 
region. In Iranian traditional medicine, $C$. botrys is used as an expectorant, anticonvulsant/antiepileptic, and tonic, as well as in the treatment of asthma (Zargari, 1993). In France and Southern Europe, $C$. botrys is used in cold and humoral asthma (Yadav et al., 2007), in Serbian traditional medicine, its dried above-ground parts are sometimes consumed as a spice, sometimes as an infusion or liquid extract, and used for diuretic, antispasmodic, carminative and antidiarrheal (Maksimovic et al., 2005). In the Skardu valley of Pakistan, the whole herb infusion is used orally to treat stomach pain, liver complaints, and headache, and it is also known as a laxative and diuretic (Bano et al., 2014). Young leaves and branches of $C$. botrys are used in wound healing in the Kohistan valley of Pakistan (Hazrat et al., 2011). In India, $C$. botrys is used as a diuretic, antispasmodic, menstrual, pectoral in asthma and cold, and it has been reported to be good for stomach and liver diseases (Khare, 2007). In Lahul, the Indian state of Punjab, C. botrys is used as a popular flavoring for meat, cheese, and barley soup (Koelz, 1979; Kletter and Krichbaum, 2001). Chenopodium botrys grown in Germany since the $19^{\text {th }}$ century is generally used against moths and as a medicinal plant (Hanelt, 2001). In Spain, it has been reported that $C$. botrys, known as "Valladolid tea" is used in the treatment of coughs and digestive system disorders and as an anthelmintic (Pardo de Santayana et al., 2005). Besides, according to previous pharmacological reports, $C$. botrys is thought to be an interesting new candidate plant for cancer treatment (Morteza-Semnani, 2015).

This study evaluates and compares various biological effects (such as antioxidant and cytotoxic) of extracts obtained from $C$. botrys species collected from the Konya region.

\section{Materials and Method}

\subsection{Plant material and extraction}

The plant material was collected from its natural habitat, and locality information of the plant specimen is Konya, Çayırbağ1, meadow slopes, $1050-1100 \mathrm{~m}$. The plant was collected and determined by Dr. Tuna UYSAL, and the voucher specimen was deposited in the KNYA herbarium (TU-3749). Firstly, the material was dried under suitable conditions without direct sunlight and moisture. Afterward, the aerial parts of the material powdered with the grinding mill were extracted with different solvents (ethanol and methanol) for 6-8 hours, respectively, with a soxhlet device. The crude extract was evaporated by a rotary evaporator. The extracts obtained were coded as CB-Met and CB-Et and stored at $+4{ }^{\circ} \mathrm{C}$ until use. The $\%$ efficiency calculations for extracts will be made according to the formula below;

$\%$ yield $=(\mathrm{A} 1 * 100) / \mathrm{A} 2$

A1 given in the formula shows the weight of the dried extract by removing the solvent, and A2 indicates the dry weight of the plant used.

\subsection{HPLC analyses}

After the extraction process, the extracts were dissolved in methanol and passed through a $0.22 \mu \mathrm{m}$ sterile filter. The prepared extracts were taken to Selçuk University Research and Development Centre for HPLC analysis. Analyses were performed with the Shimadzu instrument using the INERTSIL ODS-3V column. Working conditions were determined as $30^{\circ} \mathrm{C}$ temperature, $1.0 \mathrm{ml} / \mathrm{min}$ flow rate, and 280-330 nm wavelength. $20 \mu \mathrm{l}$ injection volume was used for each extract. In our study, four phenolic substances were scanned and quantified in our extracts. Standards were prepared by dissolving in HPLC grade methanol. Used standards; protocatechuic acid, catechin hydrate, transferulic acid, and benzoic acid. The total analysis time is approximately 45 minutes.

\subsection{Antioxidant assay}

\subsubsection{Total phenolic content}

The total phenolic content (TPC) of each extract was evaluated according to the previous method (Slinkard and Singleton, 1977; Ahmed et al., 2015). Each extract was prepared by dissolving $1 \mathrm{mg}$ per $\mathrm{ml}$. The mixture was incubated in an ultrasonic bath for 5 minutes to obtain a well-mixed solution. To $300 \mu \mathrm{l}$ of this solution taken in a tube, $3.16 \mathrm{ml}$ distilled water, $1 \mathrm{ml}$ methanol, and $200 \mu \mathrm{l}$ Folin reagent were added. Then, after incubation at room temperature, $600 \mu \mathrm{l}$ sodium carbonate solution (10\%) was added, and the tube was covered with aluminum foil and incubated in a water bath at $40^{\circ} \mathrm{C}$ for half an hour. A blank was prepared using the same procedure but replacing the plant extract with an equal volume of methanol. The absorbance of the extracts was determined at $765 \mathrm{~nm}$. The standard curve of gallic acid was obtained using the same procedure. Total phenolic content was expressed as $\mu \mathrm{g}$ of gallic acid equivalents (GAE) per ml, which was calculated using the formula, $y=0.0053 x-0.0293$ where $y$ is the absorbance at $765 \mathrm{~nm}$ and $\mathrm{x}$ is the amount of gallic acid equivalent $\left(\mu \mathrm{g} \mathrm{ml}^{-1}\right)$.

\subsubsection{DPPH analysis}

The radical scavenging activity of the extracts was measured using the DPPH test. DPPH analysis was carried out according to the $\mathrm{Chu}$ method but with minor modifications (Chu et al., 2000; Ahmed et al., 2015). The extracts were added to $0.01 \% \mathrm{DPPH}$ at various concentrations $\left(0-2.5 \mathrm{mg} \mathrm{ml}^{-1}\right)(100 \mu \mathrm{l})$ and was incubated at $37^{\circ} \mathrm{C}$ for $30 \mathrm{~min}$. Absorbance was measured at $490 \mathrm{~nm}$, and radical scavenging activity (RSA) was calculated as 50 $\%$ inhibition $\left(\mathrm{IC}_{50}\right)$ values for each sample. Also, ascorbic acid was used as the reference compound, and the $\mathrm{IC}_{50}$ value was determined.

$$
\text { DPPH RS activity }(\%)=(1-\text { A sample / A control }) \times 100
$$

\subsubsection{Reducing power activity (RPA)}

To determine the reducing power of extracts, the Oyaizu method was used (Oyaizu, 1986; Ahmed et al., 2015). Five different dilutions were prepared from each plant extract using $50 \%$ methanol (between $0-1 \mathrm{mg} \mathrm{ml}^{-1}$ ). $2.5 \mathrm{ml}$ of plant extract, $2.5 \mathrm{ml}$ of sodium phosphate buffer (0.2 M, pH 6.6), and $2.5 \mathrm{ml}$ of potassium ferricyanide $(1 \% \mathrm{w} / \mathrm{v})$ were added to each tube and mixed. The mixture was incubated at $50^{\circ} \mathrm{C}$ for 20 minutes in a water bath, then trichloroacetic acid (10 $\% \mathrm{w} / \mathrm{v}$ ) was added. $5 \mathrm{ml}$ of the mixture was placed in a test tube, and $5 \mathrm{ml}$ of distilled water and $1 \mathrm{ml}$ of ferric chloride $(0.1 \% \mathrm{w} / \mathrm{v})$ solution were added and mixed. A reducing power graph was generated by measuring the absorbance at $700 \mathrm{~nm}$. As a control, the same volume of $50 \%$ methanol was used instead of the extracts. 


\subsection{Cell culture and cytotoxic activity}

According to the previous reports, different Chenopodium species such as $C$. anthelminticum $\mathrm{L}$. and $C$. bonushenricus (L.) Rchb. were studied on the HL60 cell line, and this is the first study in C. botrys (Efferth et al., 2002; Kokanova-Nedialkova et al., 2019). For this reason, human acute promyelocytic leukemia cell line HL60 was used for cytotoxicity assignment. Cells were maintained in RPMI1640 medium (Sigma) supplemented with $10 \%$ fetal calf serum at $37^{\circ} \mathrm{C}$ in a humidified atmosphere of $5 \% \mathrm{CO}_{2}$. The prepared extracts were applied to the HL60 cell line at various concentrations $\left(0-1 \mathrm{mg} \mathrm{ml}^{-1}\right)$ and time intervals (2448h). After adding different extracts concentrations to the cell line, the cytotoxic potential of the extracts was evaluated using the MTT test. At the end of the incubation period, $5 \mathrm{mg} \mathrm{ml}^{-1}$ MTT solution was added to the cells treated with the extracts and left to incubate for 4 hours. At the end of the period, the contents of the wells were drained, and $100 \mu \mathrm{l}$ of isopropanol was added to each well to dissolve the formazan crystals formed (Mosmann, 1983). Plates were read on an ELISA reader at $540 \mathrm{~nm}$ wavelength. The effect of the extracts on cell viability was calculated by comparing the absorbance values obtained from the control group (no treatment). Analyses were done in triplicate, at least two replicates per plate. Mean values for cell viability values were taken into account. Statistical analysis was performed using GraphPad Prism 9 for Windows (GraphPad Software, San Diego, CA, USA). Data were compared using one-way ANOVA and post hoc Dunnett's test $(* \mathrm{p}<0.03, * * \mathrm{p}<0.002, * * * \mathrm{p}<0.0002$ and $* * * * \mathrm{p}<$ $0.0001)$.

\section{Results}

\subsection{HPLC results}

The quantities of the standards and the four phenolic substances in the extracts used according to the HPLC analysis are given in Table 1 and their chromatograms in Figure 1, respectively.

When we evaluate the HPLC results, we can clearly say that the phenolic compounds scanned in the extracts are found in different amounts. The most common phenolic components in the ethanol and methanol extracts were found as trans-ferulic acid and catechin hydrate, respectively. It has been determined that other phenolic components (protocatechuic acid and benzoic acid) in the content of the extracts are present in close amounts. (Table $1)$.

\subsection{Antioxidant properties of the extracts}

The total phenolic contents of the extracts were evaluated via Folin-Ciocalteu assay (Figure 2). The results showed that the linear relationship was good at detection intervals. It was determined that Chenopodium extracts prepared with ethanol have higher phenolic content $\left(78.21 \pm 2.60 \mu \mathrm{g} \mathrm{ml}^{-1}\right.$ GAE) compared to extract prepared with methanol. The DPPH assay results correlated with total phenolic content. Also, ethanolic extract shows much more free radical scavenging activity than methanol extracts. The $\mathrm{IC}_{50}$ doses of the extracts were given in Table 2 , and the $\mathrm{IC}_{50}$ dose of ascorbic acid was calculated as $21.6 \mu \mathrm{g} \mathrm{ml}^{-1}$. On the other hand, the reducing power capacities (or antioxidant potential) of the ethanolic and methanolic extracts of $C$. botrys was determined, and the results are shown in Figure
3. The ethanolic extract showed higher reducing power than the methanolic extract, similar to other experiments (TPC and DPPH). Also, the two extracts showed an almost similar tendency to decrease potency with an increase in extract concentration.

Table 1. The phenolics and amounts at the $C$. botrys extracts

\begin{tabular}{|c|c|c|c|c|c|c|}
\hline \multicolumn{7}{|c|}{ CB-Met } \\
\hline Phenolic & Unit & I. Read & II. Read & III. Read & Mean & SD \\
\hline $\begin{array}{l}\text { Protocatechuic } \\
\text { Acid }\end{array}$ & $\begin{array}{c}\text { ppm } \\
(\mathbf{m g} / \mathbf{l})\end{array}$ & 2.14 & 2.15 & 1.98 & 2.09 & 0.095 \\
\hline $\begin{array}{l}\text { Catechin } \\
\text { Hydrate }\end{array}$ & $\begin{array}{c}\text { ppm } \\
(\mathbf{m g} / \mathbf{l})\end{array}$ & 8.22 & 8.29 & 8.08 & 8.20 & 0.107 \\
\hline $\begin{array}{l}\text { Trans-Ferulic } \\
\text { Acid }\end{array}$ & $\begin{array}{c}\text { ppm } \\
(\mathbf{m g} / \mathbf{l})\end{array}$ & 0.35 & 0.33 & 0.33 & 0.34 & 0.012 \\
\hline Benzoic Acid & $\begin{array}{c}\text { ppm } \\
(\mathbf{m g} / \mathbf{l})\end{array}$ & 1.83 & 2.26 & 2.04 & 2.04 & 0.215 \\
\hline \multicolumn{7}{|l|}{ CB-Et } \\
\hline $\begin{array}{l}\text { Protocatechuic } \\
\text { Acid }\end{array}$ & $\begin{array}{c}\text { ppm } \\
(\mathbf{m g} / \mathbf{l})\end{array}$ & 1.66 & 1.73 & 1.70 & 1.70 & 0.035 \\
\hline $\begin{array}{l}\text { Catechin } \\
\text { Hydrate }\end{array}$ & $\begin{array}{c}\text { ppm } \\
(\mathbf{m g} / \mathbf{l})\end{array}$ & 4.66 & 4.46 & 4.58 & 4.57 & 0.101 \\
\hline $\begin{array}{l}\text { Trans-Ferulic } \\
\text { Acid }\end{array}$ & $\underset{(\mathbf{m g} / \mathbf{l})}{\mathbf{p p m}}$ & 9.41 & 9.45 & 9.37 & 9.41 & 0.040 \\
\hline \multirow[t]{2}{*}{ Benzoic Acid } & $\begin{array}{c}\text { ppm } \\
(\mathbf{m g} / \mathbf{l})\end{array}$ & 2.83 & 2.83 & 2.7 & 2.79 & 0.075 \\
\hline & \multicolumn{3}{|c|}{ LOD } & \multicolumn{3}{|c|}{ LOQ } \\
\hline $\begin{array}{l}\text { Protocatechuic } \\
\text { Acid }\end{array}$ & \multicolumn{3}{|c|}{0.09} & \multicolumn{3}{|c|}{0.28} \\
\hline $\begin{array}{l}\text { Catechin } \\
\text { Hydrate }\end{array}$ & \multicolumn{3}{|c|}{0.15} & \multicolumn{3}{|c|}{0.44} \\
\hline $\begin{array}{l}\text { Trans-Ferulic } \\
\text { Acid }\end{array}$ & \multicolumn{3}{|c|}{0.03} & \multicolumn{3}{|c|}{0.08} \\
\hline Benzoic Acid & \multicolumn{3}{|c|}{0.20} & \multicolumn{3}{|c|}{0.60} \\
\hline
\end{tabular}

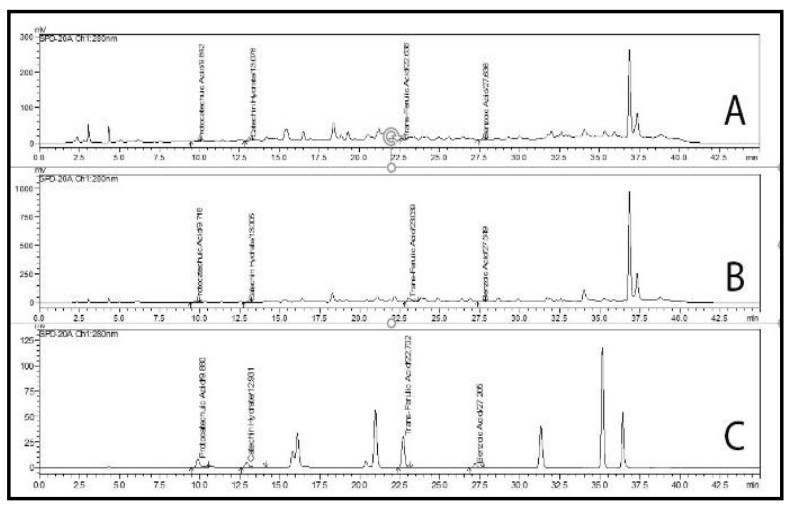

Figure 1. The chromatograms of the $C$. botrys extracts and analytic standards (A: CB-met; B: CB-et; C: standards)

\subsection{Cytotoxic potential of the extracts}

In this study, the cytotoxic activity of different $C$. botrys extracts were determined using the MTT assay on HL60 cell line exposed to $0-1 \mathrm{mg} \mathrm{ml}^{-1}$ extracts in two-time intervals (24 and 48 hours). According to the absorbance results compared with the control group, we can clearly say that both extracts show dose and time-dependent cytotoxic activity in the HL60 cell line. The \% viability graphs and $\mathrm{IC}_{50}$ doses of the extracts were given in Figure 4 and Table 2 , respectively. According to the cytotoxicity test results, it was determined that ethanolic extract was more effective on HL60 cells than methanolic extract after both 24 and 48 hours of application. 


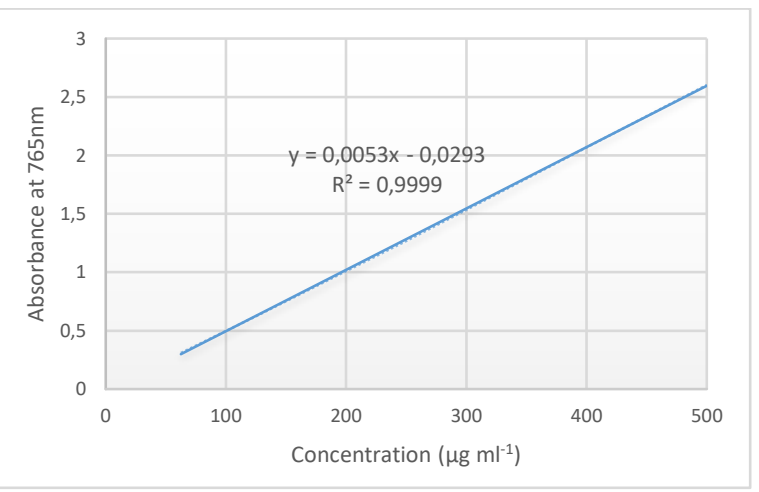

Figure 2. Gallic acid standard curve graph for Folin-Ciocalteu Assay.

\section{Discussions}

Medicinal plants have been used in traditional healthcare systems since prehistoric times and are still the most important source of healthcare for the vast majority of the world's population (Acibuca and Budak, 2018). The contribution of ethnobotanical studies to modern medicine is increasing day by day, and new inferences are made on this subject. Since most of the newly developed drugs have an orientation to natural resources and especially to plants, studies have also focused on plants and phytochemicals in this context. It has been reported that many Chenopodium species are used in traditional therapy and have numerous medicinal properties. Species in the genus are used to treat various diseases, including chest complaints, cough, abdominal pain, lung obstruction, and nervous disorders

Table 2. Antioxidant capacity and cytotoxic activities of C. botrys extracts

\begin{tabular}{|l|c|c|}
\hline Assay & CB-met & CB-et \\
\hline $\begin{array}{l}\text { the yield of the } \\
\text { extracts \% }\end{array}$ & 14.15 & 9.95 \\
\hline TPC $\left(\mu \mathrm{g} \mathrm{ml}^{-1} \mathrm{GAE}\right)$ & $69.11 \pm 1.86$ & $78.21 \pm 2.60$ \\
\hline $\begin{array}{l}\text { DPPH IC } 50 \text { values (mg } \\
\left.\mathrm{ml}^{-1}\right)\end{array}$ & $1.44 \pm 0.024$ & $0.88 \pm 0.019$ \\
\hline $\begin{array}{l}\text { MTT IC } 50 \text { values }(\mathrm{mg} \\
\left.\mathrm{ml}^{-1}\right) 24 \mathrm{~h}\end{array}$ & $0.314 \pm 0.045$ & $0.173 \pm 0.015$ \\
\hline $\begin{array}{l}\mathrm{MTT} \mathrm{IC}_{50} \text { values }(\mathrm{mg} \\
\left.\mathrm{ml}^{-1}\right) 48 \mathrm{~h}\end{array}$ & $0.210 \pm 0.051$ & $0.122 \pm 0.004$ \\
\hline
\end{tabular}

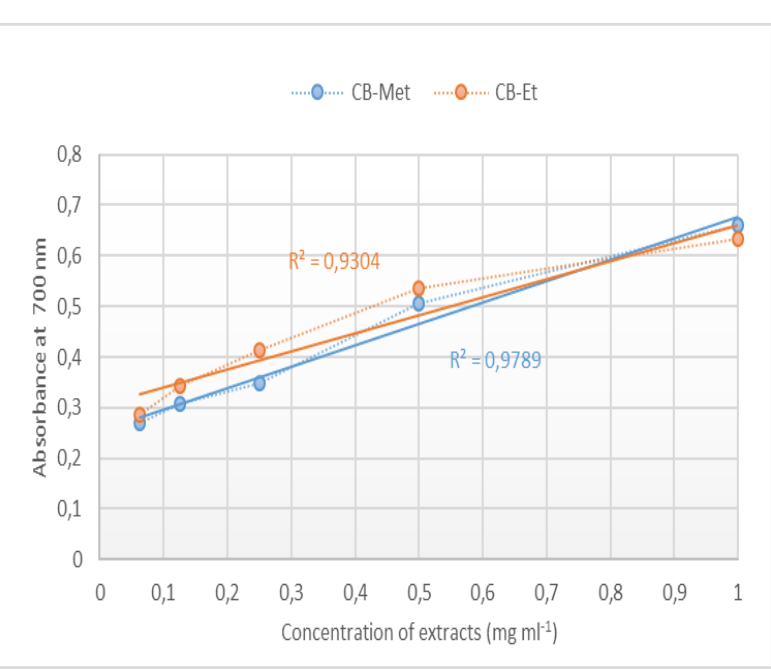

Figure 3. Reducing power of the C.botrys extracts expressed as absorbance at $700 \mathrm{~nm}(\mathrm{n}=3)$.

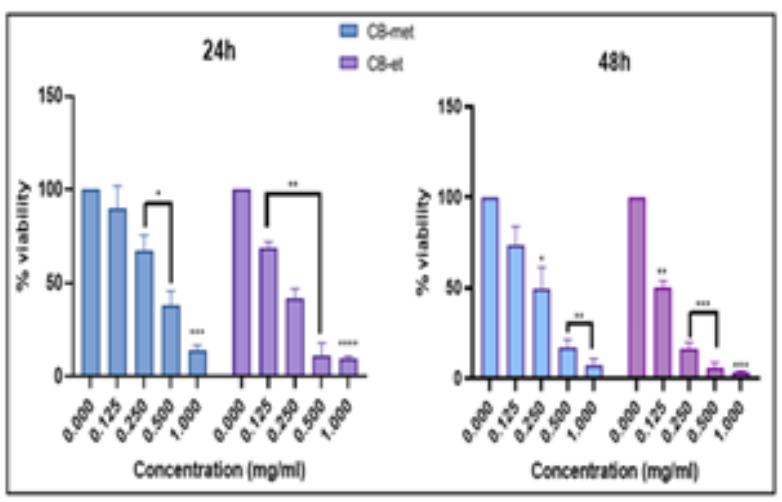

Figure 4. MTT assay graphs of methanolic and ethanolic extracts of C. botrys on HL60 cells $(* \mathrm{p}<0.03, * * \mathrm{p}<0.002, * * * \mathrm{p}<0.0002$ and $* * * * \mathrm{p}<0.0001)$.

(Yadav et al., 2007). Modern pharmaceutical research has also revealed the potent antibacterial antifungal and anticancer activities of these herbs (Bhargava et al., 2009; Khoobchandani et al., 2009; Baldi and Choudhary, 2013; Gawlik-Dziki et al., 2013; Miranda et al., 2014). As far as we know, plants from Chenopodiaceae have extremely high polyphenol content, especially flavonoids (Repo-CarrascoValencia et al., 2010). As a result of our HPLC analysis, a high rate of catechin hydrate was detected in the methanolic extract. Catechin hydrate, a phenolic compound derived from plants, is a powerful antioxidant that scavenges free radicals and has anticancer potential. Previous studies have reported that catechin exerts anticancer effects by blocking the proliferation of MCF-7 and SiHa cells (Alshatwi, 2010; Al-Hazzani and Alshatwi, 2011). Moreover, it has been reported that the highest amount of trans ferulic acid in ethanolic extract content reduces the strength and anticancer properties of reactive oxygen species. It has been reported that trans ferulic acid exhibits antiproliferative effects in the lung (H1299) and colon cancer (Caco-2) cells and increases the radiosensitivity of cervical cancer cells (Janicke et al., 2011; Karthikeyan et al., 2011; Fong et al., 2016). However, the data on cytotoxic and anticancer activities of Chenopodiaceae species are limited. According to the literature, $C$. ambrosioides L. has been reported to have a potent anti-tumor effect and the potential to prevent cancer formation (Nascimento et al., 2006; Potawale et al., 2008). Still, another study conducted on certain Chenopodium species in Poland reported that they could suppress cancer cells growing in vitro (Nowak et al., 2016). Ascaridol, one of the major components of Chenopodium genus essential oil, is reported to have a cytotoxic effect on various cell lines (CCRFCEM, HL60, MDA-MB-231) (Efferth et al., 2002). The methanolic extract of C. bonus-henricus and some of its compounds have been reported to exhibit concentration-dependent cytotoxic effects in HL60, SKW-3, Jurkat E6-1, BV-173, and K-562 cell lines ( IC $_{50}$ doses ranging 124.5-258 $\mu \mathrm{g} / \mathrm{ml}$ ) (Kokanova-Nedialkova et al., 2019). Although the results obtained in our study suggest that the cytotoxic activity of the extracts on HL60 cell lines may be due to the phenolic content, it is also thought that might be a synergistic effect as well. We have noted that there are some studies in the literature about the biological potential of $C$. botrys. The most important point that distinguishes our study from other studies is the plant's extraction technique and habitat. As known, habitat has a significant effect on the content and diversity of secondary plant metabolites. Also, the results of the plant metabolites obtained may be affected by different extraction methods. In line with this idea, both our 
extraction and plant locations are different, and the findings differ from previous reports. Andov et al. (2015) reported that the total phenolic contents of $C$. botrys species spread in Macedonia were 27.77-71.25 mg/g GAE and DPPH IC S0 $_{50}$ doses of $0.26-2.1 \mathrm{mg} \mathrm{ml}^{-1}$. Özer et al. (2016) evaluated the antioxidant capacity and enzyme inhibitory effects of ethanolic and aqueous extracts prepared by the maceration method from $C$. botrys samples collected from the Isparta region. As a result, they reported that $C$. botrys could potentially prevent various diseases, especially those associated with oxidative stress $(4.38-21.77 \mathrm{mg} / \mathrm{g}$ TE DPPH scavenging activity). In a study conducted in Pakistan, it was reported that the chloroform fraction of the methanolic extract obtained from $C$. botrys has the highest antioxidant capacity $(65.9 \pm 0.41 \mathrm{DPPH}$ scavenging activity at a concentration of $1 \mathrm{mg} \mathrm{ml}^{-1}$ ), and the plant is quite rich in bioactive compounds responsible for its antioxidant potential (Ullah et al., 2017). As far as we know, phenolic substances protocatechuic acid and catechin hydrate, which were not detected in previous studies, were detected in different amounts in our extracts. In line with the data obtained in our study, we found that both extracts have antioxidant and cytotoxic potential, and the ethanolic extract was superior to methanolic extract in terms of total phenolic, antioxidant, and reducing power, and this result was consistent with the cytotoxic effect.

As a conclusion, $C$. botrys extracts were found to contain important phenolic compounds that play an essential regulatory role in oxidation, and this study revealed that the extracts exhibit multiple biological activities such as radical scavenging and cytotoxic abilities. It is clear that this plant needs to be investigated for the isolation and characterization of new and effective phytochemicals, and we hope this study could be a precursor for future studies.

\section{Conflict of Interest}

Authors have declared no conflict of interest.

\section{Authors' Contributions}

The authors contributed equally.

\section{Acknowledgments}

We thank Selçuk University for its financial support in this study. This study was supported by Selçuk University Scientific Research Projects Coordinator (Project No: 19401125). We would like to thank Dr. Zerrin Cantürk for kindly providing the studied cell line.

\section{References}

Acıbuca V, Budak DB (2018). Dünya'da ve Türkiye'de tıbbi ve aromatik bitkilerin yeri ve önemi. Çukurova Tarım ve Gıda Bilimleri Dergisi 33(1): 37-44.

Ahmed D, Khan MM, Saeed R (2015). Comparative analysis of phenolics, flavonoids, and antioxidant and antibacterial potential of methanolic, hexanic and aqueous extracts from Adiantum caudatum leaves. Antioxidants 4(2): 394-409.

Al-Hazzani AA, Alshatwi AA (2011). Catechin hydrate inhibits proliferation and mediates apoptosis of SiHa human cervical cancer cells. Food and Chemical Toxicology 49(12): 3281-3286.

Alshatwi AA (2010). Catechin hydrate suppresses MCF-7 proliferation through TP53/Caspase-mediated apoptosis. Journal of Experimental \& Clinical Cancer Research 29(1): 1-9.

Andov LA, Karapandzova M, Jovanova B, Stefkov G, Karanfilova IC, Panovska TK, Kulevanova S (2015). Antioxidative potential of Chenopodium botrys L. (Amaranthaceae). Macedonian Pharmaceutical Bulletin 61(2): 3-10.

Baldi A, Choudhary NK (2013). In vitro antioxidant and hepatoprotective potential of Chenopodium album extract. International Journal of Green Pharmacy 7(1): 50-56.

Bandaranayake WM (2006). Modern Phytomedicine. Turning Medicinal Plants into Drugs. Weinheim: WILEY-VCH.

Bano A, Ahmad M, Ben Hadda T, Saboor A, Sultana S, Zafar M, Khan MP, Arshad M, Ashraf MA (2014). Quantitative ethnomedicinal study of plants used in the Skardu valley at high altitude of Karakoram-Himalayan range. Pakistan Journal of Ethnobiology and Ethnomedicine 10(1): 43.

Bhargava A, Shukla S, Kumar R, Ohri D (2009). Metroglyph analysis of morphological variation in Chenopodium spp. World Journal of Agricultural Sciences 5(1): 117-120.

Bodeker C, Bodeker G, Ong CK, Grundy CK, Burford G, Shein K (2005). WHO Global Atlas of Traditional, Complementary and Alternative Medicine. Geneva, Switzerland: World Health Organization.

Bozyel ME, Bozyel EM, Canlı K, Altuner EM (2019). Anticancer Uses of Medicinal Plants in Turkish Traditional Medicine. Kahramanmaraş Sütçü İmam Üniversitesi Tarım ve Doğa Dergisi 22 (Suppl. 2): 465-484.

Chu YH, Chang CL, Hsu HF (2000). Flavonoid content of several vegetables and their antioxidant activity. Journal of the Science of Food and Agriculture 80(5): 561-566.

Efferth T, Olbrich A, Sauerbrey A, Ross DD, Gebhart E, Neugebauer M (2002). Activity of ascaridol from the anthelmintic herb Chenopodium anthelminticum L. against sensitive and multidrug-resistant tumor cells. Anticancer Research 22(6C): 42214224.

Ekor M (2014). The growing use of herbal medicines: issues relating to adverse reactions and challenges in monitoring safety. Frontiers in Pharmacology 4: 177.

Fong Y, Tang CC, Hu HT, Fang HY, Chen BH, Wu CY, Yuan SSF, Wand HMD, Chen YC, Teng YN, Chiu CC (2016). Inhibitory effect of trans-ferulic acid on proliferation and migration of human lung cancer cells accompanied with increased endogenous reactive oxygen species and $\beta$-catenin instability. Chinese Medicine 11(1): 1-13.

Gawlik-Dziki U, Świeca M, Sułkowski M, Dziki D, Baraniak B, Czyż J (2013). Antioxidant and anticancer activities of Chenopodium quinoa leaves extracts-in vitro study. Food and Chemical Toxicology 57: 154-160. 
Güner A, Aslan S, Ekim T, Vural M, Babaç M (2012). Türkiye Bitkileri Listesi Damarlı Bitkiler. İstanbul: Nezahat Gökyiğit Botanik Bahçesi ve Flora Araştırmaları Derneği Yayını (In Turkish).

Hanelt P (2001). Mansfeld's Encyclopedia of Agricultural and Horticultural Crops, 1st ed. Berlin: Springer-Verlag Publishers.

Hazrat A, Nisar M, Shah J, Ahmad S (2011). Ethnobotanical study of some elite plants belonging to Dir, Kohistan valley, Khyber Pukhtunkhwa, Pakistan. Pakistan Journal of Botany 43: 787-95.

Janicke B, Hegardt C, Krogh M, Onning G, Akesson B, Cirenajwis HM, Oredsson SM (2011). The antiproliferative effect of dietary fiber phenolic compounds ferulic acid and p-coumaric acid on the cell cycle of Caco-2 cells. Nutrition and Cancer 63(4): 611-22.

Karthikeyan S, Kanimozhi G, Prasad NR, Mahalakshmi R (2011). Radiosensitizing effect of ferulic acid on human cervical carcinoma cells in vitro. Toxicology in Vitro 25(7): 1366-1375.

Khare CP (2007). Indian Medicinal Plants: An illustrated dictionary. New York: Springer-Verlag.

Khoobchandani M, Ojeswi BK, Sharma B, Srivastava M (2009). Chenopodium album prevents progression of cell growth and enhances cell toxicity in human breast cancer cell lines. Oxidative Medicine and Cellular Longevity 2(3): 160-165.

Kletter C, Krichbaum M (2001). Tibetan Medicinal Plants. Medpharm Scientific Publishers.

Koelz WN (1979). Notes on the Ethnobotany of Lahul, a province of the Punjab. Quarterly Journal of Crude Drug Research 17: 156.

Kokanova-Nedialkova Z, Nedialkov PT, Momekov G (2019). Saponins from the roots of Chenopodium bonus-henricus L. Natural Product Research 33(14): 2024-2031.

Maksimović ZA, Dordević S, Mraović M (2005). Antimicrobial activity of Chenopodium botrys essential oil. Fitoterapia 76: 112114.

Miranda M, Delatorre-Herrera J, Vega-Galvez A, Jorquera E, Quispe-Fuentes I, Martı'nez E (2014). Antimicrobial potential and phytochemical content of six diverse sources of quinoa seeds (Chenopodium quinoa Willd.). Agricultural Sciences 5(5): 1015-1024.

Morteza-Semnani K (2015). A Review on Chenopodium botrys L.: traditional uses, chemical composition and biological activities. Pharmaceutical and Biomedical Research 1(2): 1-9.

Mosmann T (1983). Rapid colorimetric assay for cellular growth and survival: application to proliferation and cytotoxicity assays. Journal of Immunological Methods 65: 55-63.

Nascimento FRF, Cruz GVB, Pereira PVS, Maciel MCG, Silva LA, Azevedo AP, Barroqueiro ES, Guerra RN (2006). Ascitic and solid Ehrlich tumor inhibition by Chenopodium ambrosioides L. treatment. Life Sciences 78(22): 2650-2653.

Nowak R, Szewczyk K, Gawlik-Dziki U, Rzymowska J, Komsta L (2016). Antioxidative and cytotoxic potential of some Chenopodium L. species growing in Poland. Saudi Journal of Biological Sciences 23(1): 15-23.

Oyaizu M (1986). Studies on products of browning reactions: Antioxidative activities of products of browning reaction prepared from glucosamine. The Japanese Journal of Nutrition and Dietetics 44: 307-315.

Ozer MS, Sarikurkcu C, Tepe B (2016). Phenolic composition, antioxidant and enzyme inhibitory activities of ethanol and water extracts of Chenopodium botrys. RSC Advances 6(69): 64986-64992.

Pardo de Santayana M, Blanco E, Morales R (2005). Plants known as té in Spain: an ethno-pharmaco-botanical review. Journal of Ethnopharmacology 98(1-2): 1-19.

Potawale SE, Luniya KP, Mantri RA, Mehta UK, Wassem MD, Sadiq MD, Veta YD, Deshmukh RS (2008). Chenopodium ambrosioides: an ethnopharmacological review. Pharmacology Online 2: 272-286.

Repo-Carrasco-Valencia R, Hellström JK, Pihlava JM, Mattila PH (2010). Flavonoids and other phenolic compounds in Andean indigenous grains: Quinoa (Chenopodium quinoa), kañiwa (Chenopodium pallidicaule) and kiwicha (Amaranthus caudatus). Food Chemistry 120(1): 128-133.

Slinkard K, Singleton VL (1977). Total phenol analysis: Automation and comparison with manual methods. American Society for Enology and Viticulture 28: 49-55.

Ullah F, Iqbal N, Ayaz M, Sadiq A, Ullah I, Ahmad S, Imran M (2017). DPPH, ABTS free radical scavenging, antibacterial and phytochemical evaluation of crude methanolic extract and subsequent fractions of Chenopodium botrys aerial parts. Pakistan Journal of Pharmaceutical Sciences 30(3): 761-766.

Yadav N, Vasudeva N, Singh S, Sharma SK (2007). Medicinal properties of genus Chenopodium Linn. Indian Journal of Natural Products and Resources 6: 131-134.

Zargari A (1993). Medicinal Plants, vol. 4. Tehran: Tehran University Publications. 